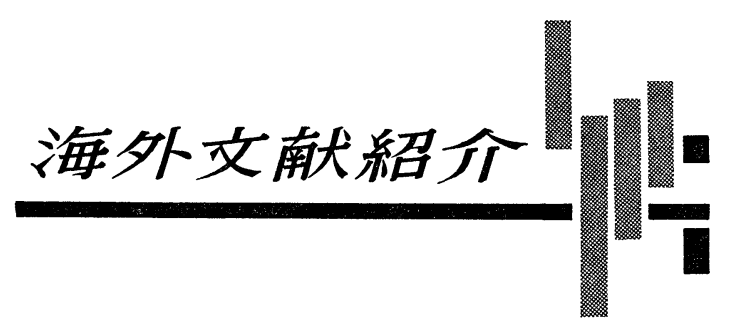

67-134 ノモグラムによる遮蔽の問題の解法

R. B. Cowdell: Nomograms Solve Tough Problems of Shielding, Electronics, Vol. 40, No. 8, Apr. 17, (1967) 92-99

抑厌すべき界の形（電界形, 磁界形, 平面波形) と周 波数を与えるととにより, 遮湤材の決定および遮蔽効果 の推定がノモグラムを使って簡単にできるととを述べて いる.

\section{1. 遮蔽効果}

電磁波の到来しているところに遮蔽のために金属板を 置く、電磁波のエネルギーの一部は金属板の表面で反射 する(これを反射損失 $R$ で表わす). 残りのエネルギーの 一部は金属板に吸収される(とれを吸収損失 $A$ で表わ す). また, 残りのエネルギーの一部は遮蔽金属板内側で 二次反射をし(これを二次反射損失 $B$ で表わす), 他は透 過する. 遮蔽効果 $S(\mathrm{~dB}$ 単位) は

$$
S=R+A+B
$$

で与えられる，とれらはすべて $\mathrm{dB}$ 単位であって， $R$ お よび $B$ は材質や電磁波の形之周波数の関数である.また $A$ は材質と周波数の関数で, 電磁波の形にはよらない. あし吸収損失 $A$ が $10 \mathrm{~dB}$ より大きい場分，二次反射損失 $B$ は無視できて,

$$
S \approx R+A
$$

となる。

\section{2. 反射損失と吸収損失}

反射損失 $R$ は，入射場と遮蔽材質の固有インピーダン スの差異による不整合のために生じる.すべての周波数 に対して電界および磁界は電磁界の存在する誘電体の固 有インピーダンスを基準として, それぞれ高インピーダ ンス, 低インピーダンスである. 遮蔽材の特性インピー ダンスは周波数と材質の透磁率および導電率によって変 化する.

入射電磁波が電界形, 磁界形, 平面波形である場合の 反射損失をそれぞれ $R_{E}, R_{H}, R_{P}$ で表わすとき，てれ らは,

$$
\begin{aligned}
& R_{E}=353.6+10 \log _{10}\left[\frac{G}{f^{3} \mu r^{2}}\right] \\
& R_{H}=20 \log _{10}\left[\frac{0.462}{r}\left(\frac{\mu}{f G}\right)^{1 / 2}\right.
\end{aligned}
$$

$$
\left.+0.136 r\left(\frac{\mu}{f G}\right)^{-1 / 2}+0.354\right]
$$$$
R_{P}=168.2+10 \log _{10}\left(\frac{G}{\mu f}\right)
$$

なる式で表わされる.とこに

$$
\begin{aligned}
& r=\text { 電波発生源と遮蔽物間の距離 (in) } \\
& \mu=\text { 遮蔽材の透磁率 (銅を } 1 \text { とする) } \\
& G=\text { 遮蔽材の導電率 (銅を } 1 \text { とする) } \\
& f=\text { 周波数 }(\mathrm{Hz})
\end{aligned}
$$

である. $R_{E}$ あ $R_{H}$ む負の值をとりうるが, これは発生 源と遮蔽材とが共振し, 遮蔽材の反射損失が負となるた めである. 本論文では $R_{E}, R_{H}$ および $R_{P}$ のノモグラム と求め方を述べている.

また, 吸収損失は電磁波が遮蔽材を通過するときの減 衰により生じ，吸収損失 $A$ は次式で与えられる.

$$
A=3.38 \times 10^{-3} t(\mu G f)^{1 / 2}
$$

$A$ は $\mathrm{dB}$ 単位で, $t$ は材料の厚さ (mil) である. 本論文 では，ての吸収損失 $A$ のノモグラムとその使用法を例を あげて述べている.

\section{3. 遮蔽材料の選択}

要求される減衰量に対し種々の金属材料およびその厚 さを求め, 重量, 強度および価格などの条件を考慮して 最終的な設計がきまる. 実際には次のようにして選定す る.まず, 電界に対する所要減衰度が $15 \mathrm{kHz}$ で $140 \mathrm{~dB}$, $1 \mathrm{kHz}$ から $2 \mathrm{GHz}$ の帯域で $120 \mathrm{~dB}$ 以上と定められてい るものとする. 高圧端子から 40 in 離れて銅板による遮 蔽が行なわれるとする. 低周波では $R_{E}$ が大きく $1.5 \mathrm{kHz}$ で $140 \mathrm{~dB}$ の隇衰をうるのは容易であるが, 高周波では $R_{E}$ が小さくなるので吸収損失 $A$ が充分大きくなるよう 厚さを決定せねばならない. $A$ の值は $A=120-R_{E}$ で 計算し，とれを“ $A$ の必要な值” の欄に書き入れ，とれ に必要な厚さ $t$ を決定する．乙れを表 1 に表わす. 厚さ $t$ の最大值, すなわち $1.2 \mathrm{mil}$ が求める厚さである.

表 1 発生源から 40 in 離れた銅板の反射損失 $R_{E}$

\begin{tabular}{c|c|c|c|c|c}
\hline 周波数 & $\begin{array}{c}\text { 反射損失 } \\
R_{E} \\
(\mathrm{~dB})\end{array}$ & $\begin{array}{c}\text { 吸収損失 } \\
\text { 豊要値 } \\
(\mathrm{dB})\end{array}$ & $t$ の厚さ & $\begin{array}{c}t=1.2 \mathrm{mil} の \\
\text { 吸収損失 } A \\
(\mathrm{~dB})\end{array}$ & $\begin{array}{c}S_{\boldsymbol{E}}=A+R_{\boldsymbol{E}} \\
(\mathrm{dB})\end{array}$ \\
\hline \begin{tabular}{c|c|c|c|c}
$1.5 \mathrm{kHz}$ \\
$\sum$
\end{tabular} & 227 & 0 & & 0.15 & 227.0 \\
$1000 \mathrm{MHz}$ & 52 & 68 & 0.62 & 130.0 & 182.0 \\
\hline
\end{tabular}

実際の遮蔽効果はこの $t$ の愿さに対しノモグラムより 計算する. この值を $S_{E}=A+R_{E}$ の欄に書く. $t$ の最大 值が求める厚さで, この場合は $1.2 \mathrm{mil}$ となる. しかし, 自体の重量を支えるためにはこれより厚さが大でなけれ ばならない。 （委員 立野・紹介者 柇山栄亮） 


\section{7-135 ノモグラムによるレーザーの $\mathrm{SN}$ 比の求め方}

$J$. Ward: Drawing a Line between Laser Signal Power and Noise, Electronics, Vol. 40, No. 10, May 15, (1967) 84-93

本論文は送受信機には振幅変調 $\mathrm{He}-\mathrm{Ne}$ レーザー，光 電增倍管を使用し，さらには雑音源として，光検波器に 背景から入る輻射（日光など）と信号ビームとによるシ ヨット雑音および二乘検波特性のため，とれら二者の相 互作用により発生するショット雑音の 2 つを考虑しなが ら, 光検波器の出力端に打ける $\mathrm{SN}$ 比を与える式を導 き，とれをノモグラフ化するととにより SN 比を簡単に 求めることができることを述べているあのである。な お，相互作用により付加される雑音は，光検波器の入力 信号が $10^{-7} \mathrm{~W}$ より大なる場合，あるいは，背景雑音を 制限するため狭率域の光学フィルターを使用し雑音スペ クトラム密度が大きくなった場合以外には省略が可能で ある。

\section{SN 比の式}

光電増倍管の周波数特性がレーザーの被変調波ビーム の全帯域で一定であるならば，検波器の出力端における 信号対雑音電力比 $(S / N)_{P}$ は次式で与えられる.

$$
\begin{aligned}
& \left.\left(\frac{S}{N}\right)_{P}=\left\{\left(\frac{\eta}{\Delta E}\right)\right\}^{2}\left(P_{S}\right)^{2}\left(\frac{k}{1+k^{2} / 2}\right)^{2}\right\} / \Delta f\left[\left(\frac{\eta}{\Delta E}\right)^{2}\right. \\
& \quad \times(2 \pi)\left(\frac{1}{\Delta \nu}\right)\left\{P_{B}{ }^{2}+\frac{1}{2} P_{B} P_{S}\left(\frac{k^{2}}{1+k^{2}}\right)\right\} \\
& \left.\quad+\left(\frac{\eta}{\Delta E}\right)\left(P_{S}+P_{B}\right)+N_{0}\right]
\end{aligned}
$$

ことに各項の定義と数值は表 1 に示す.

上式の適用例としてレーザーを衛星通信に使った場合 を想定 (図 1 参照) して考えてみる. 光送信機のビーム 幅ならびに伝搬媒質，および送受信機の能率を考慮して $P_{B}$ と $P_{S}$ を求める. $P_{S}$ については輻射 $H_{R}$ すなわち受
図 1 衛星通信に適 用したときのモ デル

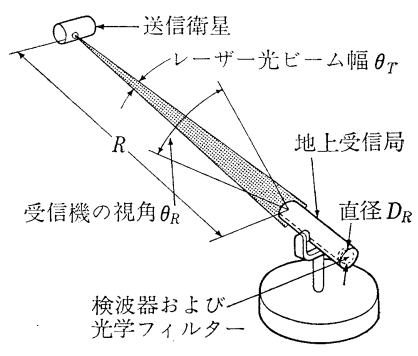

信機入力電力 $\left(1 \mathrm{~cm}^{2}\right.$ 当り) を荐える，輻射 $H_{R}$ は

$$
H_{R}=\frac{4}{\pi}\left(\frac{P_{0}}{\left(\theta_{T}\right)^{2}\left(R \times 10^{5}\right)^{2}}\right) \tau_{T} \tau_{A}
$$

となる.とれに受信機の集光口の面積と光学的能率を乗 じて, 検波器の入力信号電力 $P_{S}$ を算出すると

$$
P_{S}=H_{R}\left(\frac{\pi}{4}\right)\left(D_{R}\right)^{2} \tau_{B}
$$

となる. 光検波器に飛び込む背景雑音 $P_{B}$ は

$$
P_{B}=N_{B}\left(\frac{\pi}{4}\right)^{2}\left(D_{R}\right)^{2}\left(\theta_{R}\right)^{2}(\Delta \lambda) \tau_{R}
$$

で表わされる。乙れらの式は背景輻射雑音が受信機の視 界全域にわたっており，かつ距離 $R$ が充分大きい場合， すなわち $D_{R} \leqq \theta_{T}\left(R \times 10^{5}\right)$ の場合にのみ成立する.

検波出力信号の帯域幅を $1 \mathrm{MHz}$ として, 以上からノ モグラムを描いたのが図 2 である。帯域幅が $\Delta f$ のとき には，ノモグラムから読みとった $\mathrm{SN}$ 比を $\left(1 \times 10^{6} / \Delta f\right)$ 倍する必要がある。

\section{2.ノモグラムの使い方}

例として, 次の数值の場合, 表 1 を参照しながら $\mathrm{SN}$ 比を求めてみる.ただし信号帯域幅 $\Delta f$ は $5 \mathrm{MHz}$ とす る.

\begin{tabular}{|c|c|c|c|c|c|}
\hline 項 & 定 & 数 & 項 & 定 & 数 \\
\hline C & 光速 & $3 \times 10^{18} \AA$ & $R$ & 送受信間距離 & $\mathrm{km}$ \\
\hline$D_{R}$ & 受信機の集光口の直径 & $\mathrm{cm}$ & $(S / N)_{P}$ & 検波器出力端での信号刘雑音電力比 & \\
\hline$\Delta E$ & 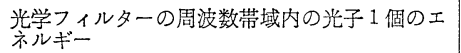 & 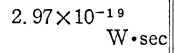 & $\eta$ & 光増倍器の量子効率 & $4 \%$ \\
\hline$\Delta f$ & 検波器のあとの光学フィルターの帯域幅 & $1 \times 16^{6} \mathrm{~Hz}$ & $\theta_{R}$ & 受信機の視角 & $50 \times 10^{-6} \mathrm{rad}$ \\
\hline$h$ & プランクの定数 & $\begin{array}{c}625 \times 10^{-34} \\
\mathrm{~W} \cdot \sec ^{2}\end{array}$ & $\theta_{T}$ & レーザー光のビーム幅 & $\mathrm{rad}$ \\
\hline$H_{R}$ & 入力輻射電力 & $\mathrm{W} \cdot \mathrm{cm}^{-2}$ & $\lambda$ & レーザー光の波長 & $6.328 \AA$ \\
\hline$k$ & 振幅変調指数 & & $\Delta \lambda$ & 光学フィルターの波長の帯域幅 & $1.0 \AA$ \\
\hline$N_{B}$ & 日光による背景雑音のスペクトル輻射 & $\begin{array}{l}2 \times 10^{7} \mathrm{~W} \cdot \mathrm{cm}^{-2} \cdot \mid \\
\text { 音体角-1. } \AA^{-1}\end{array}$ & $\Delta \nu$ & 光学フィルターの周波数帯域幅 & $74.9 \mathrm{GHz}$ \\
\hline$N_{0}$ & $\begin{array}{l}\text { 光壃倍器の暗電流パラメーター. 単位時間に輻 } \\
\text { 数 }\end{array}$ & $\begin{array}{l}10^{4} \mathrm{sec}^{-1} \\
\end{array}$ & $\tau_{A}$ & 空間の伝送効率 & $70 \%$ \\
\hline$P_{B}$ & 背景雑音の検波器入力電力 & $\mathrm{w}$ & $\tau_{R}$ & 受信機の光学的伝送効率 & $40 \%$ \\
\hline$P_{0}$ & 送信機の光学系を通過する前のレーザー出力 & $\mathrm{W}$ & $\tau_{T}$ & 送信機のレーザー出力の光学的伝送効率 & $40 \%$ \\
\hline$P_{S}$ & レーザービームの検波器入力電力 & $\mathrm{w}$ & & & \\
\hline
\end{tabular}

$R=10^{5} \mathrm{~km}, P_{0}=100 \mathrm{~mW}, k=0.50, \theta_{T}=10 \times 10^{-6} \mathrm{rad}$ $D_{R}=100 \mathrm{~cm}, \theta_{R}=50 \times 10^{-6} \mathrm{rad}$

（1）目盛(1)の上にレーザー電力 $P_{0}$ をとり，目盛(2) の上に送受信機間の距離 $R$ をとり直線で結び, 直線(3)

表 1 ノモグラムおよび式の各項目についての定義と数值 


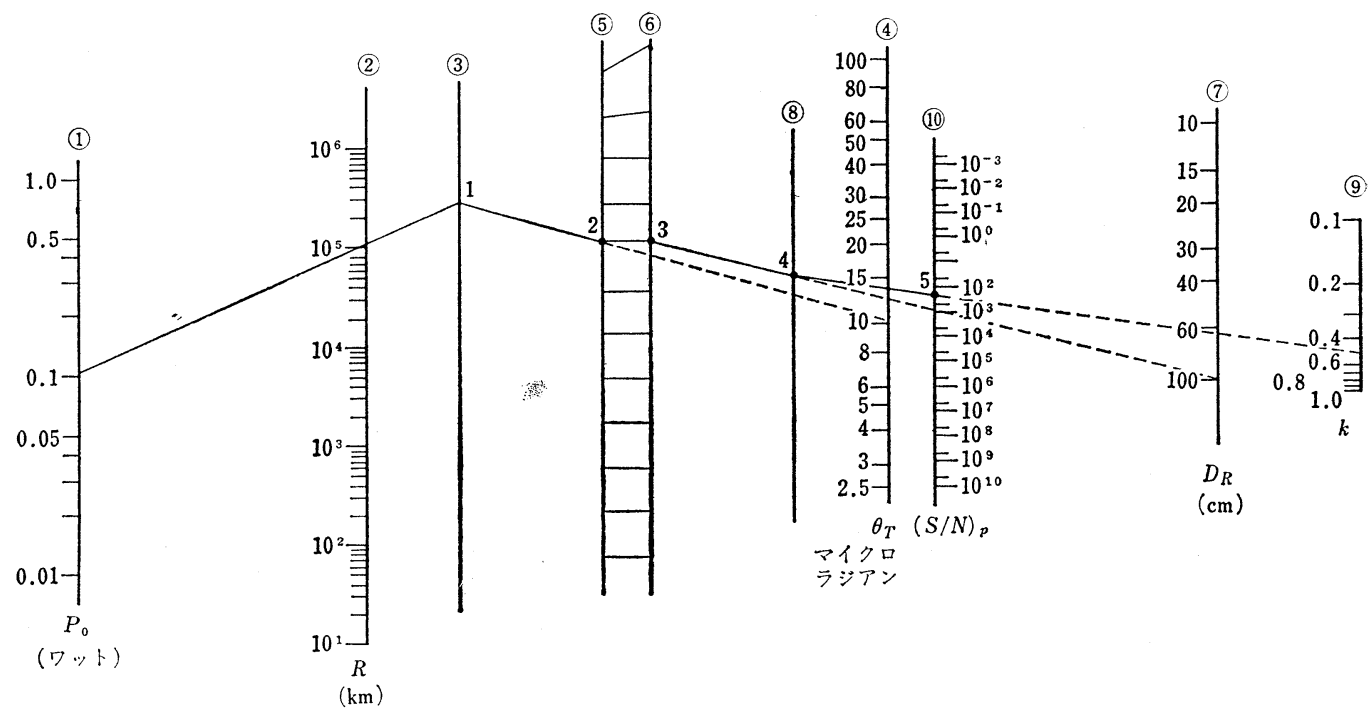

図2,モグラム

の交点 1 をとる.

（2）上の点 1 と送信ビーム幅 $\theta_{T}$ を目盛(4)の上にと り，とれら 2 者を結び直線(5)との交点 2 をとる.

(3) 点 2 に対応する直線(6)上の点 3 を求める.

(4) 受信機の集光口径 $D_{R}$ を目盛(7)上にとり点 3 と 結ぶ.とれと直線(8)との交点 4 をきめる.
（5）目盛(9)上に変調指数 $k$ の值をとり，乙の点と点 4 を結び，この直線と目盛 (10) との交点 5 から $\mathrm{SN}$ 比は $2.82 \times 10^{2}$ となる. これは $1 \mathrm{MHz}$ に対する值であるから $5 \mathrm{MHz}$ の帯域幅に対しては $2.82 \times 10^{2} \times\left(1 \times 10^{6} / 5 \times 10^{6}\right)$ $=56.4$, すなわち求める信号対雑音電力比は 56.4 であ る.

（委員 立野・紹介者 杉山栄亮

\section{4-148 LSA ダイオード—ミリ波域 での出力}

LSA Diodes: Power at Millimeter Waves, International Electronics, Jun.-Jul., (1967) 29-31

一LSA はダイオードの新しい発振モードを用いるもの であり，他の固体発振装置，たとえばトランジスタ，ト ンネルダイオード, IMPATT ダイオードなどより大出 力で高周波の発振が得られる.

ベル研究所の J. A. Copeland は, 常温で $88 \mathrm{GHz}$ にお いて $20 \mathrm{~mW}$ の CW 出力をLSA ダイオードで得ている. これは, 固体 $\mathrm{CW}$ 発振装置によるものとしては, 最む高 い周波数である. また， $51 \mathrm{GHz}$ では $0.7 \mathrm{~W}$ のパルス 電力, $40 \mathrm{~mW}$ の $\mathrm{CW}$ 電力が得られている.

\section{1. 高周波発振}

LSA 以外の固体発振装置では, 使用しうる最高周波 数は, 空間電荷が装置内を走行する時間で制限される. ゆえに高周波で使用するには，動作領域を狭くして走行 時間を短くせねばならない。

一方, LSA ダイオード発振器では, 空間電荷は蓄積 される前に物質中で消散するので, 走行時間により発振 周波数が制限されない。ゅえに印加電圧が大きくても耐 えられるだけ厚くできる.また，発振周波数は，共振回

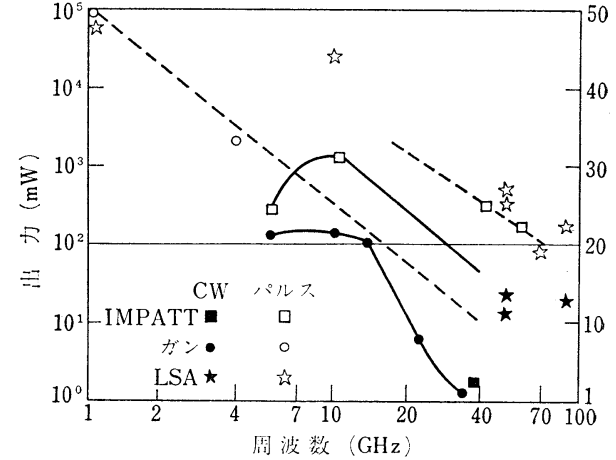

図 13 種類の固体ダイオード発振器に ついての出力と周波数の関係

路でほぼ定まるので, 出力の大きさは周波数と無関係に なる. $\mathrm{RF}$ 発振出力は, ダイオードに印加される電王が スレシホールドを越えると, $n$ 形 $\mathrm{GaAs}$ が負抵抗を呈す ることにより得られる.

\section{2. ガン発振形}

これまでの LSA ダイオードは, 低周波域でのガン発 振器として設計されたものを用いてきた。しかし，LSA 効果を充分発揮させるには, 電流の流れる方向を長くし これと直角方向を薄くしなければならない，将来最適の 形状が得られれば，従来の走行時間応用装置より数段大 


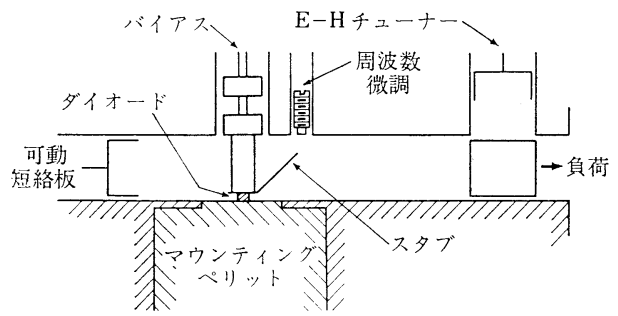

図 $244 \sim 88 \mathrm{GHz}$ 帯用のベル製 LSA 発振回路

きな出力を出せるだろう.

ベルで使われた実際の回路を図 2 に示す，一次共振回 路は装置のキャパシタンスとスタブのインダクタンスか ら成る. $300 \mathrm{~ns}$ パルスを用いたとき，乙の回路の効率は $9 \%$ ある。，一次㑡発振と導波管の整合は，スタブと導 波管の底面との角度を変化させてとる，発振周波数の調 整は，スタブの長さを変えるととにより行なう。この発

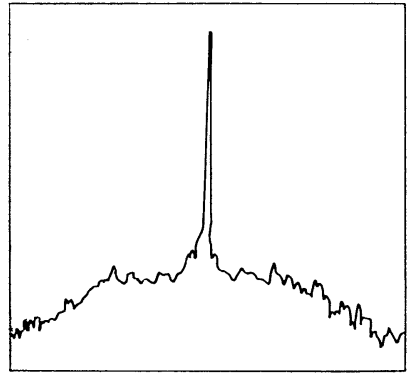

図 $351 \mathrm{GHz}$ における LSA 発振器の出力 スペクトル

振スペクトルを図了に示す.

\section{3. 伝 送系}

LSA ダイオードは, PCM 伝送系において, 数百Vで 動作しているクライストロンの代りに試験的に用いられ ている. このダイオードは，寿命が長くしかも小形にで きる特徴をむっている. (委員 伊藤・紹介者 吉川憲昭)

\section{7-151 ドイツ連邦共和国における テレビフィルムの技術基準}

K.E. Gondesen: Technical Specification for Television Films in the Federal Republics of Germany, Journal of the SMPTE, Vol. 76, No. 4, (1967) 335-340

この論文は，本誌Vol. 19，No. 6 (1965) で紹介した Kino Technik B 18, No.18(1964) と一部重複する個所 があるが，内容的には新しくテレビ用フィルムの粒状 性，変調度などの限界值，乙れらを测定するための测定 装置, 放送用フィルムの送出法, 画音同期の新しい録音 方式について述べてる.

\section{1. テレビ用フィルムの諸特性}

（a）最大コントラスト：ディテールを再現しなけれ ばならないテレビ用フィルムの最適コントラストは, $D=1.6$ に対応した $1: 40$ が一般に受け入れられてい る.

（b）白濃度と変換特性：FSSによるテレシネ系で良 好な SN 比を得るためのフィルムの白濃度は,できるだ け小さいほうが良く, 最適白濃度は $D_{\min }=0.25$ である. 最終ポジ像の変換特性は少なくとも図 1 の許容笵囲に入 るととが必要である.

(c) 変調度 (レスポンス特性): $35 \mathrm{~mm}$ フィルムは, 比較的高感度のフィルムであ変調度が $5 \mathrm{MHz}$ で $90 \%$ あ るのに対して, $16 \mathrm{~mm}$ フィルムでは反転の ASA 100 で $60 \%$ ，ネガ ASA 100 で 48\%， ネガ ASA 200 で $32 \%$ と かなりの低下を示す．図 2 に $16 \mathrm{~mm}$ 反転フィルムを使 ったフィルム送像系のレスポンス特性を示す. $16 \mathrm{~mm}$ レシネ系で $5 \mathrm{MHz}$ のオーバーオールレスポンスは $50 \%$ であるが， $35 \mathrm{~mm}$ に対しては少なくとも $80 \%$ に相当す る.

（d）粒状性：フィルムの粒状性は乳剂の性質以外に

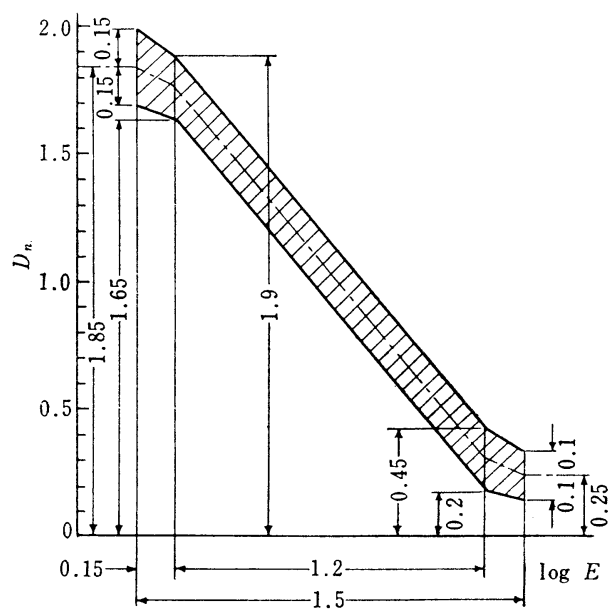

図 1 テレビ用フィルムの変換特性の許容範闻

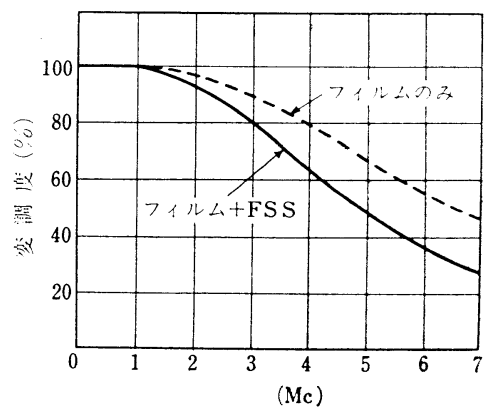

図 $216 \mathrm{~mm}$ テレシネチェーンの変調度

処理条件にも依存する。このため，粒状性は標準の処理 条件で測定しなければならない。図了はフィルムの濃度 の関数として, (1) $16 \mathrm{~mm}$ フィルム+FSS テレシネチ エーン, (2)フィルムのみ(フィルム测定装置)，（3）フ ィルム(テレビ信号に変換)の SNR 值を示す. との四か 


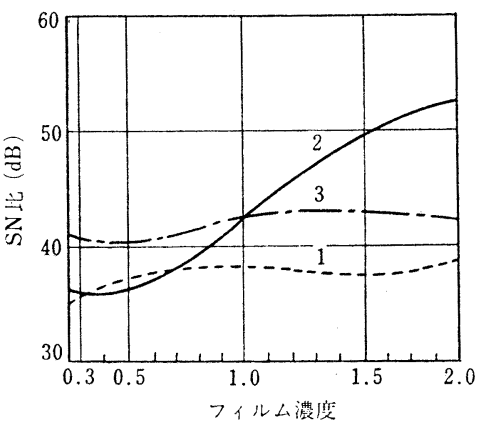

図316 mm 反転フィルムとテレシネチェーンの $\mathrm{SN}$ 比

う，標準コントラスト範囲 1：40に打けるFSS の SNR は $35 \mathrm{~mm}$ では $52 \mathrm{~dB}$ (乙れは生放送と同等)まで, 16 $\mathrm{mm}$ では $46 \mathrm{~dB}$ まで澾成することができるととがわ 加る.

\section{2. フィルム測定装置}

フィルム测定装置はFSSのテレビフィルム走査と同 じような動作原理で, 同じアパーチャ一条件, 同一站查 系, 同タイプの光電管を有している. 図4 亿装置の系統 図を示す.フィルム試料部は円形のダイアフラムによっ て回転している 2 インチスクリーン上に，適当な大きさ 亿抎大して投影される。拡大率は $16 \mathrm{~mm}$ フィルムに対 して 85 倍, $35 \mathrm{~mm}$ フィルムに対して 35 倍である. 回転 しているスクリーン上のダイアフラムの径は, CCIR テ レビ系のラインスペースに相当し，フィルム像の高さの 約 $5 \%$ をカバーするように，中心から 0.6 インチに調整 されている. 走查光束はミラー系によって光電管に向け てある.この装置によって次の测定を行なうととができ る.

（a）透過率抢よび濃度值（黒白以外に色フィルタ 一濃度も测定可能)

（b）振幅一周波数特性（変調度）

(c) 粒状性 (SNR)

\section{3. テレビ用白黒フィルムの基準}

テレビ用フィルムにとって重要な諸因子は $D_{\max }, D_{\min }$ ” 裂換特性, 変調度(レスポンス), 粒状性であり, その基 滇值を表 1 亿示す.

\section{4. 放送用フィルムの送出法}

調整に当って，2つのタイプのグレイスケールパター

表 1 テレビ用白黒フィルムの重要な特性

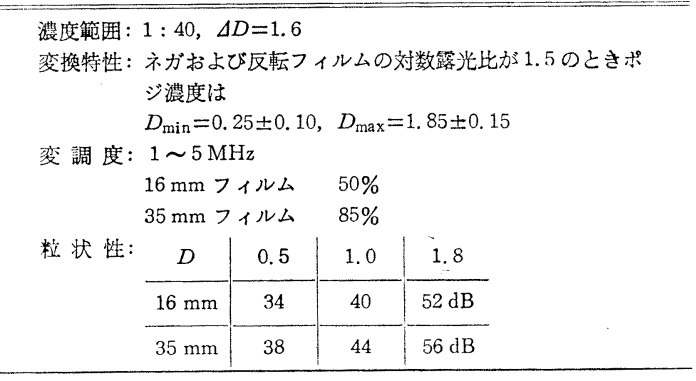

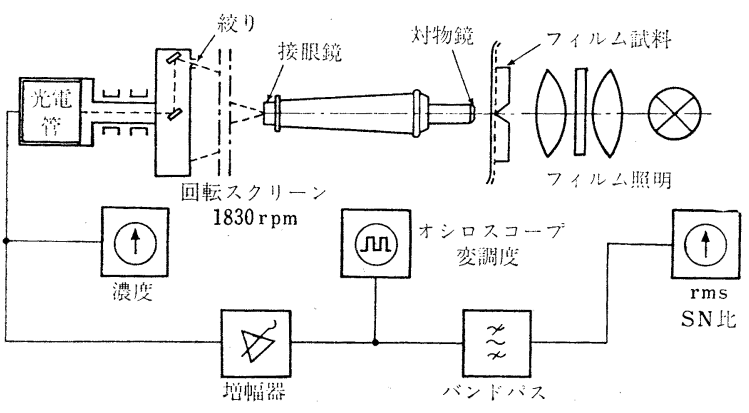

図 4 フィルム測定装置

ンが使われ，双方とむ $50 \%$ のテレビ信号振幅に相当し た $D=0.75$ の周辺濃度をむっている.タイプ1は 5 段 階のグレイスケールで, その濃度值は利得抢よびガンマ 補正を適当にしたときに，オシロ上で白から黒までのレ ベルが直線となるようなものが選ばれる。タイプ2は図 1 の変換特性に相当した 11 段階のグレイスケールで, て れはオシロ上で直線的とはならないが，全再生系のチェ ックに使う.

\section{5. 画音同期録音}

1 トラックに2つのヘッドがあり，互いに涩しない で録音再生を行なうことができる Neopilot 方式を採用 している.乙の方式は，同期信号をへッドの両端にプッ シュプル方式で記録するので，音声と同期信号は完全に 分離され， $\mathrm{SN}$ 比，周波数特性は $6 \mathrm{~mm}$ テープ録音と同 等である.

(委員 藤尾・紹介者 家木健至)

\section{7-336 明日の世界でテレビジョンに期待 されるもの}

G. H. Brown: Televison's Role in Tomorrow's World, IEEE Spectrum, Vol.4, No. 10, Oct., (1967) $56-58$

末来諭が流行る昨今である，しかしながら，末来を語 るということは, 至難のわざであるから, 長期予測では 仮りに予測した時点に現実がそうならなかったとして あ，どんなととをいわれたか誰も覚えていないであろう というととを頼りにせざるを得ないし，また，短期予测 ではどんな事態が招来しようとも説明がつくような， あ いまいな表現を使わざるを得ないというのが，未来論の 一般準則であある.

ところで, 今日の通信技術の最す顕著な様相は, テレ ビ, ラジオ，電話といった各種のエレクトロニックメデ イア閒の，伝統的な区別がなくなり，代わって、これら をいっしょにし，さらには計算機を中核とするデータ好 理系を含めた形の統一されたシステムという方向に動い ているととである，すなわち，近い将来における主要な 情報媒体は，との統一されたシステムが当るととになる であろう。そしてそのときには，複雑なわがテレビ技街 
も，きわめて重要でかついままで以上に巧妙なむのにな っているにしても，全体の一部に過ぎないものになって いるであろう.

これらのととを期待できる背景としては，集積回路技 術などの進歩により電子機器はますます小形軽量になり さらに，テレビで必須である光電（および電光）変換系 あ，管を用いなくてできるようになるであろうというと と, また，広帯域衛星通信技術の進歩によりテレビの到 達範囲は全世界的なあのになる，などをあげるととがで きよう。との時点ではテレビとて，現在の電話とまった く同じような用途に使われるととになるであろう.

さて，テレビには，現在放送というマスメディアとし ての形態と, 閉回路テレビという限定されたメディアと

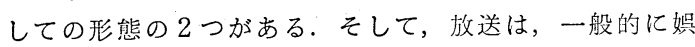
楽のための媒体としての側面が大きくクローズアップし ているが，広範に普及するととにより，グループ（ある いは個人) 教育用, 気象予報, 農作物情報, 海事情報, 交通情報など，専門化した用途に対する需要と機能が生 じてくるだろう。そうすれば，閉回路テレビと同様な性 格がクローズアップすることが考えられるのである.

計算機を活用した統一された通信システムを駆使し, 各種の情報サービスを行なうための情報センターの出現 も予想される。そのときには放送事業の形態も現在とは
大きく変化し，電子印刷技術などの助けを借りた多角経 営も考えられる.

しかし，とのような事態が世界のどてにでも同時に生 じてくると考えることは早計というもので, 複雑な計算 機のプログラミングは高度に発達した文明社会に扣いて だけ意味のあるととなのである。それが期待できる社会 というのは, 北アメリカ, ヨーロッパそれに日本であ る.その他の開発途上国では，社会進歩のために必要な 教育レベルを上げるととが第一に求められるととであ る。それがために低廊な端末装置および受信装置を使っ た衛星通信に期待がかけられるのである.

UNESCOの推計によると，ひとつの国が自国民に適 切な情報を提供するには，人口 100 人当り，1つの日刊 紙の10のコピーと，5つのラジオあるいはテレビの受信 機之， 2 つの映画用の席が要るというととである．東 南アジアならびにアフリカおよびラテンアメリカの大部 分の国では，むちろんての基準などはとんであないとと である。これらの地域で情報サービス機関が欠乏してい るという結果のひとつは，極端な国では，国民の 4 分の 3 以上が文盲という事実となって現われている。乙れら の地域にこそ教育用衛星通信の必要が叫ばれるゆえんで ある．との場合，テレビに期待されるととはその効果の 点からしても最む大きいといわねばなるまい.

（委員・紹介者 立野 敏)

\section{7-157 静電集束形プランビコン実験管}

J.H.T. van Roosmalen: Experimental Electrostatically Focused "Plumbicon" Tubes, Philips Technical Review, Vol. 28, No. 2, Feb., (1967) 60-66

静電集束方式は電磁集束方式にくらべ集束のための電 力が少なくてよく, また, 集束調節で画像の回転が起と らず，大きさも変わらないなどの利点があり，カラーカ メラ用として好適である. 図1は静電集束形プランビコ ン実験管の概略断面図である. 集束は $\mathrm{A}_{1}, \mathrm{~A}_{2}, \mathrm{~A}_{3}$ か ら成るユニポテンシャルレンズで行ない,ターゲットへ 垂直ランディングさせるための補正レンズは, 集束レン ズ $\mathrm{A}_{3}$ とメッシュ付きのリング電極 $\mathrm{R}$ でできている．偏 向コイルの位置, 補正レンズの構成と電位が静電集束系 の問題であり, ランディングエラーとひずみについての 計算と実験を行なった.

メッシュの位置で電子ビームが管軸となす角度を $\alpha$, メッシュの電位を $V_{M}$ とすると, 電子ビームのランディ ングエラーは $V_{M} \sin ^{2} \alpha$ で表わされる。図 2 は $a=1.0$ $\mathrm{mm}, b=3.0 \mathrm{~mm}, p=50 \mathrm{~mm}$ で計算したランディング エラーである. $V_{M}=660 \mathrm{~V}$ のンディングェラーは $r=$ $7 \mathrm{~mm}$ まではきわめて小さく, 最大で $0.04 \mathrm{~V}$ である. $V_{M}=600 \mathrm{~V}$ の場合, むっと広い面積にわたってランディ ングエラーは許容できる範围にある.ランディングエラ 一はターゲットの中心 $(r=0)$ ともう 1 カ所 $\left(r=r_{0}\right)$ で零 となる. $r>r_{0}$ でのランディングエラーが $r<r_{0}$ でのラ

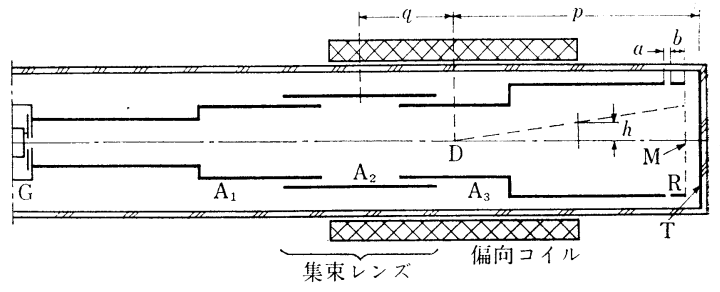

図 1 静電集束形プランビコン垁験管の断而図

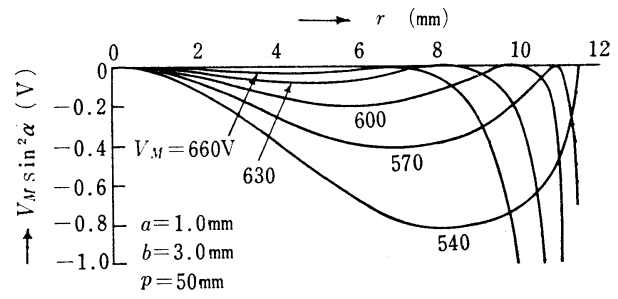

図 2 ランディングェラーの計算例

ンディングエラーの最大值に等しくなる $r\left(=r_{F}\right)$ は，タ 一ゲットの有効半径の目安となるが, $p=50 \mathrm{~mm}$ では $b$ $=3 \mathrm{~mm}$ で $r_{F}$ が最大となる．また， $p$ が大きくなれば $r_{F}$ は大きくなる.

集束を良くするため, 集束レンズと偏向コイルとの相 互作用領域を引き離す必要があり, 実験では $q$ を電子レ ンズの直径以上にした，また，偏向コイルを補正レンズ の方向に近づけると信号電流の一様性は悪くなり,ひず 


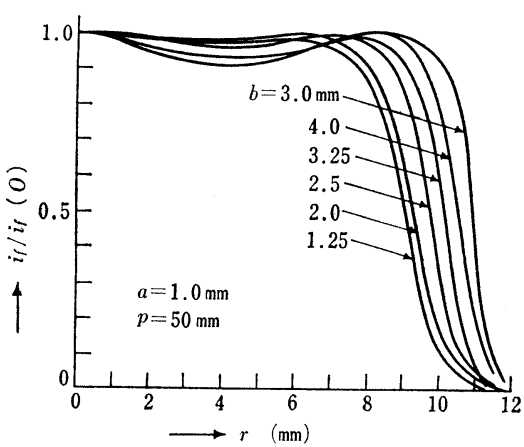

図 3 出力信号の一様性の実験結果

みあ多くなる，てのため，偏向コイルを集束レンズから 充分に離し，補正レンズからも離すという相反する条件 は，偏向コイルの長さを短くして満足させた。

図了は $a=1.0 \mathrm{~mm}, \quad p=50 \mathrm{~mm}$ でターゲット電压を
$2 \mathrm{~V}$ にし，ターゲットを一様に照明して测った信号電流 $i_{f}$ で， $r=0$ で規格化したものである. $i_{f} / i_{f}(0)$ がほぼ 1.0 亿等しいターゲットの有効部は， $b=3.0 \mathrm{~mm}$ のとき 最大で, $p=60 \mathrm{~mm}$ であほぼ同じで計算結果とまったく 一致している.また，ランディングエラーは $p=50 \mathrm{~mm}$ $b=3.0 \mathrm{~mm}$ では $0.3 \mathrm{~V}, p=60 \mathrm{~mm}, b=3.0 \mathrm{~mm}$ では $0.15 \mathrm{~V}$ で，乙の値も計算と良く合っている. メッシュ 電王を高くすると画像の一様性が良くなるが, ターゲッ トの有効部が減り，計算と同じ結果が得られた.

補正レンズの使用によって，ある程度のたる形ひずみ が生ずるが，このひずみはレンズの構成，印加電生，编 向中心の位置で変わる． pが大きいほど， ランディング エラーと同じくひずみは少ないが，bについてはランデ ィングエラーと違って最適値はなく，bが大きいほどひ ずみが大きくなる。

(委員 辻・紹介者 煀 浩雄)

\section{7-159 タンタル薄膜受動素子の 製法と応用}

R. Naylor and R. Fairbank: The Preparation and Application of Tantalum Thin Film Passive Components, The Radio and Electronic Engineer, Vol. 33, No, 4 Apr., (1967) 229-240

\section{1. 概 説}

半導体集積回路之薄膜素子は互いにライバルのように 思われていたが, 最近では両者の特長を生かし，相補的 任使用するととが最す有効な手段であると考えられるよ うになってきた，たとえば，半導体集積回路における拡 散受動素子は薄膜受動素子に劣るが, 一方, 薄膜では現 在のととろ能動素子ができないという欠点がある。

\section{2. 受動素子}

a) 抵 抗

拡散抵抗は総合誤差が $\pm 20 \%$ とかなり悪く,また, 抵抗温度係数も $0.1 \sim 0.5 \% /{ }^{\circ} \mathrm{C}$ とあまり良くない。しか したとえば，タンタル薄膜抵抗を使えば誤差士5\%，抵 抗温度係数 $0.01 \%$ とするととができる. 薄膜抵抗とし
ては主にタンタルとニクロムが使われているが，特にタ ンタルは空素を少量ドープすると, ニクロムより高い比 抵抗が得られる.

タンタル薄膜を作るにはスパッタリング技術を使う。 これはタンタルが高融点物質なので普通の真空蒸着技術 が使えないととや，スパッタリングを使うと広い面積に わたって均一な膜が得られるととによる。タンタル薄膜 の面積抵抗は $10 \sim 300 \Omega /$ in $^{2}$ が可能である.

b) キャパシタ

拡散キャパシタに対する薄膜キャパシタの利点のひと つは，大きい容量值が得られるととである。たとえば， 五酸化タンタルの誘電率は約 21 で, シリコン酸化物の それは 2 〜 にすぎない。五酸化タンタルはタンタルを 陽極酸化することによって得られ，酸化膜の厚さは陽極 酸化電圧によってきまる。たとえば， $80 \mathrm{~V} て ゙$ 陽極酸化す ると厚さ $1,200 \AA$ の酸化膜ができる。

タンタル薄膜キャパシタの損失は小さいが, 高周波で は電極の抵抗分による損失が主となるので, 下部電極に シリコン基板をそのまま使えばよい（図 1).

漏洩電流は，たとえば $1,200 \mathrm{pF}$ のキャパシタに $15 \mathrm{~V}$

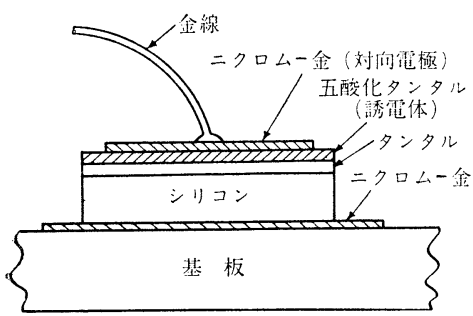

図 1 薄膜タンタルキャパシタ の構造

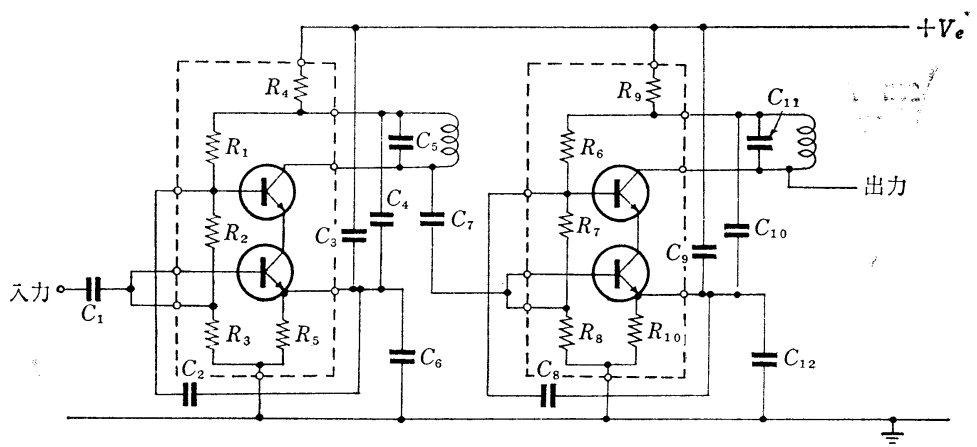

図 22 段中間周波增幅器回路図 


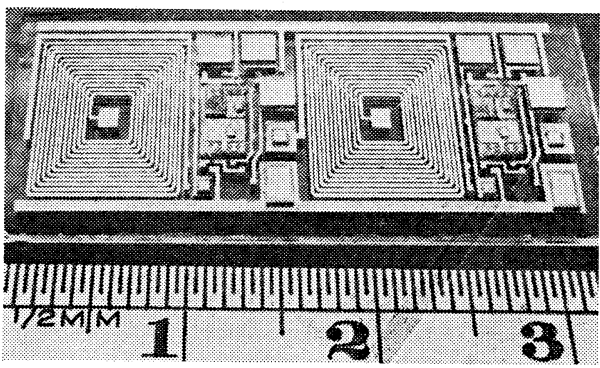

写真 12 段中間周波增幅器

のバイアス電圧をかけたとき室温で $10^{-9} \mathrm{~A}, 150^{\circ} \mathrm{C}$ に温 度を上げてす $5 \times 10^{-7} \mathrm{~A}$ である。耐圧は約 40 〜 $50 \mathrm{~V}$ ， すなわち陽極酸化電圧の $50 \%$ はもつ。

c）インダクタ

薄膜技術もインダクタについてはあまり有効ではな い.インダクタンスを大きくするため多層構造にすると
とや，実効透磁率の大きい材料を使うととが考えられて いるが，いまのととろ数 $\mu \mathrm{H}$ が限度である.

d）薄膜回路に能動素子を使う方法

現在のところ, 薄膜能動素子はまだ研究段階で, 回路に 応用するまでにはいたっていない，そこで能動素子に半 導体チップを使い，乙れを薄膜受動素子でできている回 路基板上につけて集積化するか, シリコン基板に拡散で 能動素子を作り，これをシリコン酸化物などで覆って保 護し，その上に薄膜受動素子をつけて回路を構成するか のいずれかが使われる.

\section{3. 薄膜技術の回路への応用}

薄膜受動素子を使った回路としては，低周波 $\mathrm{R}-\mathrm{C}$. 発 振器, 広带域増幅器, NAND ゲート回路などがあるが, 代表例として 2 段の中間周波増幅器をあげる. 図 2 はそ の回路図，写真 1 は全体の写真である.

（委員 辻・紹介者 長坂浩生）
(71ページから)

67-287 S. Miluschewa: The Solar System Environment. 754-766

最近の実験データから得られた惑星空間環境.

IEEE Transactions on Electron Devices (Vol. ED-14, No. 6, Jun., 1967)

*67-288 P. H. Wendland: A Charge-Storage Diode Vidicon Camera Tube. 285-291

電荷蓄積の問題を中心とした半導体（特に $\mathrm{Si}, \mathrm{Ge}$ ) ダイオード接合 の設計理論と簡単な実験.

67-289 T.-F. Shao, L.P. Hunter: The Physical Mechanism of the Chargister in Terms of Minority Carrier Exclusion and Injection. 306-313

Chargister の動作原理

IEEE Transactions on Electron Devices (Vol. ED-14, No. 7, Jul., 1967)

67-290 C. C. T. Wang: Computor Calculation of Deffection Aberrations in Electron Beams. 357-365 電磁偏向した電子ビームの収差を, 1 次元偏向の場合について計算 (IBM 7094) した.

IEEE Transactions on Microwave Theory and Techniques (Vol. MTT-15, No. 8. Aug., 1967)

67-291 R. A. Kolker: The Amplitude Response of a Coupled Transmission Line, All-Pass Network Having Loss. 438-443

伝送系に結合した損失分を有する全通過回路の電圧伝達関数を求め てれが伝搬定数の実数部で定まるととについて記述.

*67-292 H. Guckel, P. A. Brennan, I. Palócz: A Parallel-Plate Waveguide Approach to Microminiaturized, Planar Transmission Lines for Integrated Circuits. 468-476 IC 用の平面伝送路を二平面導波管と近似し伝送姿態や伝送特性を 求めている.

Information Display (Vol. 4, No. 5, 1967)

67-293 E. H. Hieborn, L.E. Stevenson: Means for Improving Apparent Television Resolution. 40-43

带域を增加するととなく解像力を堌大する方法の一提案

International Broadcast Engineer (No. 34, Jul., 1967)

67-294 C. Garnes: Automatic Program Control and Colour
Television in Japan. 220-222

日本に㧍ける計算機制御番組送出装置と 2 管式カラーカメラの紹 介.

*67-295 M. D. Benedict: The Natlock System. 228-231

BBC における Genlock 方式 (C. L.N.P.S., Andlock, Natlock)

Journal of the SMPTE (Vol. 76, No. 9, Sept., 1967)

*67-296 E. H. Brown: A Method for Measuring the Spatial-Frequency Response of a Television System. 884-888

テレビ系の空間周波数レスポンスを測定する簡単な方法.

*67-297 I. K. Macdonald, J.Y. Roy: A Regenerated Sideband Demodulator for Television. 888-892

失わ机た側波帯を再生することにより残留倒波帯伝送における位相 ひずみ，直交ひずみを軽減する方法の解析と実験結果.

Kino-Technik (Vol. 21, No. 8, Aug., 1967)

*67-298 F. Meier: Der Farbfilm und das Fernsehen. 177182

映画用カラーフィルムの研究結果は，だいたいカラーテレビ用フィ ルムにも適用できるが，特にテレビ用カラーフィルムの場合輝度コ ントラストなどについて特別な要求がなされる.

Microwaves (Vol. 6, No. 9, Sept., 1967)

*67-299 J. G. Tatum : Microwave Transistor-Parameter Trade-Offs in Circuit Design. 26-32 トランジスタの動作定数がマイクロ波回路動作に及ほす影響につい て記述.

67-300 H.S. Jones: Integrated Radome-Antenna Design. 34-39

ラドームとアンテナを 1 個に結合して作るととにより重量やスペー ス，コストの低下がはかられるが，てのアンテナの電気的特性につ いて記述.

NTZ (Vol. 20, No. 8, Aug., 1967)

*67-301 F. Th. Backers: Einige Betrachtungen über die PAL-Verzögerungsleitung. 473-477

PAL カラーテレビ用遅延線の所要特性と Philips で設計した遅延 線について記述. 